ACTA UNIVERSITATIS LODZIENSIS

FOLIA LITTERARIA POLONICA 4(34) 2016

http://dx.doi.org/10.18778/1505-9057.34.05

Szymon Piotr Dąbrowski*

\title{
Wiersze pochwalne na cześć Elżbiety z Branickich Sapieżyny i jej najbliższych krewnych
}

Historycy zainteresowani literaturą okolicznościową doby stanisławowskiej od dawna podkreślali fakt, iż poczynania księżny Elżbiety z Branickich Sapieżyny stały się przyczyną krytycznych sądów, niejednokrotnie bardzo ostro wyrażanych w paszkwilach rozpowszechnianych ze szczególnym nasileniem w okresach konfliktów politycznych ${ }^{1}$. Uwagę przyciągały przede wszystkim szydercze wiersze, które w czasie Sejmu Wielkiego najpewniej wyszły spod pióra Franciszka Zabłockiego $^{2}$, a także powstałe w latach siedemdziesiątych poezje Tomasza Kajetana Węgierskiego na czele ze słynnymi Portretami pięciu Elżbiet... ${ }^{3}$. Magnatkę nazywaną po drugim mężu wojewodzicową mścisławską, a przez pewien czas kochankę

${ }^{*}$ Doktorant, Uniwersytet Śląski, Wydział Filologiczny, Zakład Historii Literatury Baroku i Dawnej Książki Instytutu Nauk o Literaturze Polskiej im. Ireneusza Opackiego, 40-032 Katowice, pl. Sejmu Śląskiego 1; e-mail: szymon.piotr.dabrowski@gmail.com

${ }^{1}$ S. P. Dąbrowski, Uwagi o „Porankach kodeńskich”'Ignacego Potockiego, ,Wschodni Rocznik Humanistyczny" 2014, t. 10, s. 189-198; tegoż, Portrety Elżbiety z Branickich Sapieżyny w paszkwilach obyczajowych i politycznych, w: Codzienność i niecodzienność oświeconych, [cz.] 2: Wrezydencji, w podróży i na scenie publicznej, red. B. Mazurkowa, z udziałem M. Marcinkowskiej i S.P. Dąbrowskiego, Wydawnictwo Uniwersytetu Śląskiego, Katowice 2013, s. 139-152, Prace Naukowe Uniwersytetu Śląskiego w Katowicach, nr 3072. W obu tych artykułach odnotowane są kluczowe prace poświęcone pamfletowym portretom arystokratki.

${ }^{2}$ R. Kaleta, O twórczości satyrycznej Franciszka Zabłockiego w okresie Sejmu Czteroletniego, w: tegoż, Oświeceni i sentymentalni. Studia nad literatura $i$ życiem $w$ Polsce $w$ okresie trzech rozbiorów, Zakład Narodowy im. Ossolińskich - Wydawnictwo, Wrocław 1971, s. 542-596. Por. również uwagi Krystyny Maksimowicz w książce: Poezja polityczna a Sejm Czteroletni, Wydawnictwo Uniwersytetu Gdańskiego, Gdańsk 2000, s. 5-11, 13-14.

${ }^{3}$ Należy również wskazać, że anonimowi paszkwilanci atakowali dobre imię księżny już w czasach konfederacji barskiej, o czym ostatnio przypomniała Krystyna Maksimowicz w rozprawie: Portretowy soterion i jego kulisy: „Powinszowanie księżnie Elżbiecie z Branickich Sapieżyn<ie> szczéśliwego do zdrowia powrócenia”, w: Czytanie Naruszewicza, [cz.] 1, red. B. Wolska, T. Kostkiewiczowa i B. Mazurkowa, Instytut Badań Literackich PAN Wydawnictwo, Warszawa 2015, s. 289, Czytanie Poetów Polskiego Oświecenia, t. 3, cz. 1. 


\section{Stanisława Augusta ${ }^{4}$ paszkwilanci najczęściej oskarżali o rozpustne zachowanie} i szkodliwe dla kraju ambicje polityczne.

Ze względu na znaczną liczbę tych obraźliwych konterfektów, a także różnorodność i ciężar wysuwanych w nich zarzutów nie może dziwić - niepozbawiona pewnej przesady - opinia wyrażona swego czasu przez Krystynę Maksimowicz: „Wśród ocen wydanych Sapieżynie trudno znaleźć pozytywną”5. Jednak mimo tego sądu i jemu podobnych ${ }^{6}$ badacze odnaleźli kilka utworów pochwalnych napisanych na cześć księżny ${ }^{7}$. Celem rozważań podjętych w rozprawie jest przybli-

${ }^{4}$ M. Czeppe, Sapieżyna z Branickich Elżbieta, w: Polski stownik biograficzny (dalej: PSB), t. 35, Warszawa 1994, s. 163-167. Jeśli nie zaznaczono inaczej, wszelkie informacje dotyczące poczynań księżny podawane są za tą pracą. Dodatkowe wiadomości na temat życia i publicznej działalności wojewodzicowej zawierają studia Witolda Filipczaka (tegoż, Elżbieta Sapieżyna na tle politycznej roli kobiet w czasie kampanii sejmowej z 1778 roku, w: Niebem i sercem okryta. Studia historyczne dedykowane dr Jolancie Malinowskiej, red. M. Malinowski, Wydawnictwo Adam Marszałek, Toruń 2002, s. 303-326; tegoż, Stanisław August i Elżbieta Sapieżyna. Spór wokół losów sejmu 1782 roku, w: Władza i polityka w czasach nowożytnych, red. Z. Anusik, Wydawnictwo Uniwersytetu Łódzkiego, Łódź 2011, s. 53-75) i Andrzeja Tłomackiego (tegoż, Sapiehowie. Linia kodeńska, Wydawnictwo „Mada”, Warszawa 1996, m.in. s. 102-111, 239-242; tegoż, Sapiehowie kodeńscy. Historia rodu od kolebki do wspótczesności, Andrzej Tłomacki, Warszawa 2009, m.in. s. 129-144).

${ }^{5}$ K. Maksimowicz, Poezja polityczna..., s. 87.

${ }^{6}$ Problemem wartym podjęcia w kontekście badań nad literackimi portretami Sapieżyny jest - jak się wydaje - kwestia wyraźnego związku między jej szyderczymi konterfektami, przede wszystkim z czasów Sejmu Wielkiego, a nie zawsze trafnymi ocenami badaczy dotyczącymi arystokratki i jej publicznego wizerunku w czasach stanisławowskich. Por. rozważania Iwony Węgrzyn, która dostrzegła podobieństwo sylwetki Franciszka Ksawerego Branickiego ukształtowanej w paszkwilach okresu czteroletnich obrad i refleksji pisarzy dziewiętnastowiecznych poświęconej losom hetmana (tejże, Polskie piekło. Literackie biografie zdrajców targowickich: Stanisława Szczęsnego Potockiego, Franciszka Ksawerego Branickiego i Seweryna Rzewuskiego, Universitas, Kraków 2005, s. 188-197).

${ }^{7}$ Dotychczas w literaturze przedmiotu odnotowano osiem utworów pochwalnych na cześć wojewodzicowej mścisławskiej. Najbardziej znane jest pochodzące z roku 1770 Powinszowanie księżnie Elżbiecie z Branickich Sapieżyn<ie> szczęśliwego do zdrowia powrócenia Adama Naruszewicza (Poezje zebrane, t. 1, wyd. B. Wolska, Instytut Badań Literackich PAN Wydawnictwo Akademia Humanistyczna, Warszawa 2005, s. 170-172, 231, 312-313, Biblioteka Pisarzy Polskiego Oświecenia, t. 4). Trzy lata później imieniny księżny uczcił Kajetan Kościałkowski, publikując w redagowanym przez siebie periodyku poetyckim (numery z 20 i 27 listopada 1773 roku) Odę do J[aśnie] O[świeconej] księżny Jejmci Sapieżyny, wojewodzicowej mścisławskiej, z okoliczności jej imienin przypadtych dnia 19 Novembra w dzień ś[więtej] Elżbiety oraz Wiersz z okoliczności fajerwerku i balu wyprawionego dla J[aśnie] O[świeconych] i J[aśnie] W[ielmożnych] Elizbiet kosztem J[aśnie] W[ielmożnego] Jmc[i] pana hetmana polnego koronnego dnia 18 Novembra w Warszawie. Owe teksty nie zostały jak dotychczas krytycznie wydane (,Muza Ukryta pod Znakiem Herbu Syrokomli" 1773, t. 1, tydzień 2, k. [7]; tydzień 3, k. [9], Biblioteka Jagiellońska, sygn. 931/I). Ponadto księżna jako jedna z pięciu sławionych dam wspomniana została w anonimowej Odzie do ojczyzny na dzień 19 listopada w roku 1774 (Wiersze polityczne pierwszego rozbioru i sejmu delegacyjnego 1772-1775, oprac. B. Wolska, Wydawnictwo Sejmowe, Warszawa 2001, s. 293-297). Znamiona utworu pochwalnego ma również poetycka reakcja na słynny pamflet Węgierskiego Re- 
żenie okoliczności powstania, głównych motywów treściowych oraz kompozycji i artystycznego ukształtowania tych laudacyjnych portretów, które dotychczas nie przyciągnęły uwagi autorów zajmujących się piśmiennictwem okolicznościowym i politycznym ${ }^{8}$. Są one warte bliższego zainteresowania zarówno historyka, jak i literaturoznawcy, wiążą się bowiem z nieznanymi epizodami publicznych poczynań magnatki, wzbogacają galerię wizerunków kobiet epoki stanisławowskiej, a ponadto stanowią wyjątkowo rzadkie znaleziska - do tej pory udało się zlokalizować pojedyncze egzemplarze poszczególnych druków.

Pierwszym z nich jest wiersz podarunkowy nieznanego autora, opatrzony tytułem: Do Jaśnie Oświeconej księżnej Jejmości Elżbiety z Branickich Sapie$\dot{z} y n y$, wojewodzicowej $m<\dot{s}>$ cisławskiej, $w$ dzień imienin 19 Novembris 1784 w Prenach. Tego wolantu nie notuje kompendium Estriecherów ani „Nowy

spons w obronie pięciu Elżbiet... kasztelana przemęckiego Rafała Gurowskiego. Utwór ten nie został wydany w epoce, podobnie jak tego samego autora wiersz Na dzień imienin jednej z J[aśnie] W[ielmożnych] Elżbiet w Warszawie („Zbiór różnych rytmów...” oraz pism, s. 448-449, 505, Zakład Narodowy im. Ossolińskich, rkps 14262/III). Nie tylko zresztą poeci kierowali wyrazy uznania pod adresem wojewodzicowej. W 1780 roku bernardyn i królewski teolog Wenanty Tyszkowski opublikował we Lwowie Teatrum myśli..., zbiór trzynastu dialogów poświęconych zagadnieniom eschatologicznym. Dzieło to poprzedził skierowanym do magnatki listem dedykacyjnym oraz wierszem na herby Branickich i Sapiehów (Jaśnie Oświeconej księżnie Jmci Elżbiecie z Branickich księżnie Sapieżynie, wojewodzicowej mścisławskiej, pani i dobrodzice, w: tegoż, Teatrum myśli albo zdań $z$ soba walczacych $w$ materiach silu rozróżnionych religii szukajacym prawdy otworzone, przez siedmiu aktorów zagajone. Tomik o miejscach osobliwych razem z światem catym stworzonych do ukarania wszystkich grzesznych, od samegoż Stwórcy wyznaczonych, Drukarnia Bractwa Św[iętej] Trójcy, Lwów 1780, k. $\left.\mathrm{A}_{2} \mathrm{r}-\left[\mathrm{A}_{4}\right] \mathrm{v}\right)$. Ostatnim odnotowanym przez badaczy utworem pochwalnym na cześć arystokratki jest powinszowanie Antoniego Chądzyńskiego. Tenże protegowany magnatki jest autorem Ody w dzień imienin Jaśnie Oświeconej księżnej Jejmości Elżbiety Sapieżyny, wojewodziny mścisławskiej, ofiarowanej od... kapitana gwardii pieszej koronnej, dnia 19 listopada 1788, Warszawa [1788], k. nlb. 2, Biblioteka Instytutu Badań Literackich PAN, sygn. XVIII.2.534.

${ }^{8}$ Poza wskazanymi już artykułami Krystyny Maksimowicz i Marii Czeppe (zob. przypisy nr 3 i 4) wierszowane i prozatorskie pochwały pod adresem Elżbiety Sapieżyny zostały zauważone lub były przedmiotem zwięzłych uwag w kilku innych pracach: E. Aleksandrowska, Kościatkowski Kajetan, w: PSB, t. 14, Wrocław 1968-1969, s. 391; J. W. Gomulicki, Młody ,gniewny” polskiego oświecenia, w: [T.]K. Węgierski, Wiersze wybrane, wybrał, tekst ustalił oraz wstępem poprzedził J. W. Gomulicki, Państwowy Instytut Wydawniczy, Warszawa 1974, s. 22-23; B. Wolska, Poezja politycza czasów pierwszego rozbioru i sejmu delegacyjnego 1772-1775, Zakład Narodowy im. Ossolińskich - Wydawnictwo, Wrocław 1982, s. 259-260, Studia z Okresu Oświecenia, t. 19; tejże, Reminescencje antyczne w poezji Kajetana Kościałkowskiego na łamach „Muzy Ukrytej pod Znakiem Herbu Syrokomli”, „Prace Polonistyczne” 1985, t. 41, s. 177; tejże, „, Muza Ukryta pod Znakiem Herbu Syrokomli” Kajetana Kościatkowskiego, „Prace Polonistyczne” 1989, t. 45, s. 30-33; tejże, Ogólne uwagi o twórczości okolicznościowej Adama Naruszewicza. Wiersze podarunkowe i bukiety, „Prace Polonistyczne” 2004, t. 59: Tobie - teraz. W kręgu literackich ofiarowań, s. 134; S. P. Dąbrowski, Wizja przestrzeni eschatologicznych w „Teatrum myśli...” Wenantego Tyszkowskiego, w: Światy oświeconych i romantycznych. Doświadczenia, uczucia, wyobraźnia, red. B. Mazurkowa, Wydawnictwo Uniwersytetu Śląskiego, Katowice 2015, s. 156, Prace Naukowe Uniwersytetu Śląskiego w Katowicach, nr 3343. 
Korbut"9. Formuła tytułowa powinszowania, określająca utwór jako wypowiedź skierowaną do adresatki w konkretnym miejscu i czasie, sugeruje, że druk z wierszem ofiarowano wojewodzicowej w dzień imienin świętowanych przez nią w litewskiej miejscowości, gdzie znajdowała się siedziba starostwa jej syna Kazimierza Nestora Sapiehy ${ }^{10}$. Myśl o obecności arystokratki w tym miejscu 19 listopada podsuwa również wzmianka poczyniona w okolicznościowym wierszu. Przybliżając zalety solenizantki, nieznany autor stwierdził: „Ten ci bukiet twe Preny niosą w imieniny" (w. 12). Z listu pisanego przez księżnę z Olity w przeddzień jej święta do kanclerza wielkiego koronnego i biskupa poznańskiego Antoniego Onufrego Okęckiego wynika, że po zakończeniu sejmu w Grodnie (co nastąpiło 13 listopada ${ }^{11}$ ) arystokratka udała się do starostwa jedynaka. Celem tego wyjazdu był - jak to sama określiła - „kielkodniowy odpoczynek"12. A zatem magnatka przybyła do majątku syna krótko po zamknięciu obrad, natomiast później znalazła się w Olicie, miejscowości położonej trzydzieści kilometrów na południe od dóbr Sapiehy. Stamtąd 18 listopada wysłała list do kanclerza, a wkrótce być może ponownie zawitała do Pren, gdzie - jak sugerują tytuł i wzmianka zamieszczona w omawianym wierszu - obchodziła imieniny. Nie sposób jednak definitywnie rozstrzygnąć tej kwestii. Najpewniej ktoś uznał za stosowne zorganizowanie przyjęcia w związku z wizytą arystokratki w litewskim starostwie ${ }^{13}$, co nie może zaskakiwać, skoro - jak wiadomo z uwag zawartych w wierszu - Sapieżyna odwiedziła Preny po raz pierwszy. Autor informował o tym fakcie, konkretyzując okoliczności ofiarowania utworu w początkowym fragmencie powinszowania.

${ }^{9}$ Do Jaśnie Oświeconej księżnej Jejmości Elżbiety z Branickich Sapieżyny, wojewodzicowej $m<\dot{s}>$ cisławskiej, $w$ dzień imienin 19 Novembris 1784 w Prenach, [b.m.] [1784], k. nlb. 2, Biblioteka Narodowa, sygn. XVIII 2.7049. Utwór cytowany jest według tej edycji.

${ }^{10}$ Zob. uwagi poświęcone związkom tytulatury imieninowych utworów z okolicznościami ich napisania, druku i podarowania: B. Wolska, B. Mazurkowa, T. Chachulski, Oświeceniowa poezja imieninowa, w: Wiersze imieninowe poetów z drugiej połowy XVIII wieku, wstęp, wybór tekstów i oprac. B. Wolska, B. Mazurkowa, T. Chachulski, Instytut Badań Literackich PAN Wydawnictwo, Warszawa 2011, s. 30-38.

${ }^{11}$ Chronologia sejmów polskich 1493-1793, zestawił i wstępem poprzedził W. Konopczyński, Polska Akademia Umiejętności, Kraków 1948, s. 168 [42] (poz. 242), Archiwum Komisji Historycznej - Polska Akademia Umiejętności, seria 2, t. 4 (18), nr 3.

${ }^{12}$ E. Sapieżyna do A. O. Okęckiego, Olita, 18 listopada 1784, w: Korrespondenz der Fürsten Sapieha. 1709-1798, Archiwum Główne Akt Dawnych, Archiwum Komierowskich, rkps 12/12, s. 173.

${ }^{13}$ Odwiedzający Litwę w 1778 roku Johann Bernoulii pokrótce opisał Preny w swojej relacji, co jest warte odnotowania, ponieważ pod datą 18 września wskazał on miejsca, gdzie mogła odbyć się imieninowa uroczystość: „Jechaliśmy przez góry, doliny i lasy, przeważnie złymi drogami, do Pren [...], rozległej miejscowości z wielkim drewnianym zamkiem, obok którego stał mniejszy, nowy, murowany pałac" (Podróż po Polsce 1778, w: Polska stanisławowska w oczach cudzoziemców, t. 1, oprac. i wstępem poprzedził W. Zawadzki, Państwowy Instytut Wydawniczy, Warszawa 1963, s. 330). 
Stwierdził tam między innymi: „Księżno, gdy się raz pierwszy widzieć Prenom dajesz" (w. 5). Natomiast zamykając pochwały, zwrócił się z uprzejmą prośbą do solenizantki: „Przyjm, księżno, to, co szczerość uprzejma wyraża / I radość ludu, pierwszy raz widząc swe pany” (w. 37-38). Bez względu na termin uroczystości istnieje również możliwość, że w trakcie przyjęcia odczytano wierszowany podarunek, który - po uzyskaniu aprobaty adresatki - został wydrukowany i ofiarowany jej w charakterze okolicznościowej pamiątki ${ }^{14}$. Lecz także w tym przypadku trudno cokolwiek przesądzać, zbyt mało bowiem wiadomo na temat ówczesnych poczynań wojewodzicowej. Nie jest jasne, jaki faktycznie cel miała wizyta księżny w Prenach i co dokładnie oznaczały te odwiedziny dla mieszkańców. Nie ma podstaw, by podważać przytaczane już zapewnienie o odpoczynku, lecz wydaje się, że ów przyjazd nie tylko do tego się sprowadzał. Sapieżyna mogła bowiem po zakończonym sejmie odzyskiwać siły w Kodniu, gdzie znajdowała się jej siedziba. Mimo to - zaraz po zamknięciu obrad - zdecydowała się przyjechać do Pren pierwszy raz od czasu, gdy ponad dziewięć lat wcześniej jej syn Kazimierz Nestor został uhonorowany godnością starosty ${ }^{15}$. Możliwe więc, że celem wizyty było także poprowadzenie - bliżej nieznanych - spraw jedynaka, ważnych również dla kogoś miejscowego; interesów, których pomyślna realizacja mogła także pośrednio zależeć od przygotowania odpowiedniej oprawy na przyjazd księżny.

Bez względu na czas druku i rzeczywiste powody, a nie wyłącznie okolicznościowe względy, dla których powstał ów wiersz, nieznany autor pragnął stworzyć wrażenie, że zawarte w utworze pochwały Sapieżyny zostały sformułowane w imieniu preńskich obywateli - zaszczyconych i poruszonych przybyciem arystokratki. Fakt, że laudacyjny utwór ma zbiorowego nadawcę, a twórca tego wiersza, będący wyłącznie wyrazicielem przekonań owego gremium, pozostaje nieznany, przesądza o instytucjonalnym charakterze tekstu ${ }^{16}$. Wpływa to także na ukształtowanie pochwał, ponieważ komplementy pod adresem księżny są wypowiadane w powinszowaniu niejako z perspektywy członków wspólnoty, którzy pierwszy raz ją widzą i wypowiadają sądy na jej temat. W związku z takim ujęciem utwór rozpoczyna refleksja poświęcona atrybutom nieprzeciętnych jednostek oraz wpływowi, jaki wywierają one na innych ludzi:

${ }^{14}$ Zob. ustalenia i uwagi Jerzego Wojciecha Zawiszy poświęcone nierzadko skomplikowanym sytuacjom komunikacyjnym okolicznościowych tekstów laudacyjnych: Panegiryczny druk okolicznościowy doby stanisławowskiej, Zakład Narodowy im. Ossolińskich - Wydawnictwo, Wrocław 1984, s. 37-45, Śląskie Prace Bibliograficzne i Bibliotekoznawcze, t. 18.

${ }^{15}$ Kazimierz Nestor uzyskał dożywotnią dzierżawę starostwa preńskiego decyzją sejmu z 5 września 1775 roku, natomiast dobra objął dopiero w roku 1782, po śmierci Michała Butlera, poprzedniego właściciela tego majątku (Ł. Kądziela, Sapieha Kazimierz Nestor, w: PSB, t. 35..., s. 52, 53). Data nadania skłania do wniosku, że za tym wyróżnieniem stała matka księcia, który wówczas przebywał w Strasburgu. Por. M. Czeppe, Sapieżyna..., s. 164.

${ }^{16}$ J. W. Zawisza, Panegiryczny druk okolicznościowy..., s. 45-47. 
Szczęśliwy, kto wielkością duszy słabszych dziwi,

Szczęśliwszy, kto wejrzeniem jednym serca bierze,

Najszczęśliwszy, w kim rozum mocny ludzkość żywi.

Któż się wielkim prawdziwie nazowie w tej mierze?

Księżno, gdy się raz pierwszy widzieć Prenom dajesz,

Panią serc czułych cnoty wszystkim się nam stajesz.

(Do Jaśnie Oświeconej księżnej... w Prenach, w. 1-6)

Następstwo przywoływanych zalet wybitnej indywidualności, a także wprowadzenie ich w ramy gradacyjnego wyliczenia, stopniującego niejako stan szczęśliwości osiągany przez nadzwyczajną postać, nie są przypadkowe. Nieznany autor ustanowił w ten sposób wyraźną hierarchię przymiotów będących świadectwem znakomitości nieprzeciętnej jednostki. Czynnikiem warunkującym kolejność, a zarazem wagę i znaczenie zaszczytnych cech jest tu oddziaływanie na życie zbiorowości osoby odznaczającej się tymi cnotami. Stąd autor wiersza najpierw ogólnie wspomina o walorach duchowych, przyjmowanych przez obserwatorów - jak wskazuje w pochwalnej refleksji - wyłącznie z zaskoczeniem, a zatem oddziaływanie tych przymiotów na społeczność było najmniejsze. Z kolei wspomnienie o „wejrzeniu” sygnalizuje wyżej cenioną łagodność usposobienia, która umożliwia zjednanie ludzkich serc, a więc pozyskanie otoczenia dla własnych zamiarów. Natomiast siła rozumu wymieniona na końcu wyliczenia została uznana za przymiot najcenniejszy, ponieważ stanowi źródło pożytecznych działań podejmowanych na rzecz zbiorowości, będąc tym samym przyczyną faktycznych korzyści członków wspólnoty ${ }^{17}$. Określeniu oznak prawdziwej wielkości towarzyszy pytanie, komu można przypisać tak skonkretyzowane walory. Odpowiedź została ujęta w ramy apostrofy do solenizantki nazwanej „Panią serc czułych cnoty” (w. 6). Ów zabieg pośrednio, lecz jednoznacznie wskazuje na księżnę jako uosobienie rozważanego

${ }^{17}$ Początkowa partia utworu nawiązuje do motta, którym wiersz został opatrzony, i stanowi jego rozwinięcie. Oto epigraf i jego przekład - S.P.D.:

Il est facile, à la grandeur

De régner toujours, sur notre âme

Un coup d'œil gagne notre cour

Une politesse l'enflamme
Łatwo wielkości

Panować zawsze nad naszą duszą. Jednym spojrzeniem zdobywa nasze serce, Grzecznością je rozpala.

Motto zostało zaczerpnięte - jak w okolicznościowym druku informuje podpis pod cytatem - z wiersza François de Malherbe'a. Przywołaną przez francuskiego autora politesse ('grzeczność lub uprzejmość) należy w tym kontekście rozumieć jako określony sposób bycia i postępowania w ramach wspólnoty, który jest konsekwencją bywania w świecie, a także - świadectwem szlachectwa. Zob. na ten temat: B. Craveri, Złoty wiek konwersacji, przekł. J. Ugniewska i K. Żaboklicki, Oficyna Naukowa, Warszawa 2009, zwłaszcza s. 19-20, 22-25, 480-481. Zob. także: T. Kostkiewiczowa, Ambiwalencje grzeczności: „Do... («Żądasz waszmość pan...»)”, w: Czytanie Krasickiego, red. T. Kostkiewiczowa, R. Doktór i B. Mazurkowa, Instytut Badań Literackich PAN Wydawnictwo, Warszawa 2014, s. 323-325, Czytanie Poetów Polskiego Oświecenia, t. 2. 
ideału; wzoru, który - co zostało wyrażone w drugiej strofie utworu - realizuje w życiu wyłącznie jednostka odznaczającą się odpowiednimi, to znaczy pożądanymi, wysoko cenionymi zaletami. Autor wiersza wskazał tu, że nie znaczenie „rodu, bogactwa, domu i imienia” (w. 7), lecz osobiste walory, takie jak „Rozum, mądrość, przezorność, chęć dobrze czynienia” (w. 9), są niezawodnymi oznakami wielkości. Wyższe uznanie dla osobistych przymiotów będących potwierdzeniem faktycznej wartości człowieka niż dla atrybutów świadczących wyłącznie o wysokiej pozycji społecznej przybliża omawiany utwór do nowych schematów pochwalnych, które w swoich tekstach realizowali twórcy oświeceniowi, chociaż samo wspomnienie o koligacjach i majątku jest w pochwalnej refleksji również pośrednio wyrażonym komplementem, a więc nawiązaniem do tradycyjnych motywów laudacyjnych ${ }^{18}$.

Następne strofy okolicznościowego wiersza zawierają odrębną grupę pochwał, skoncentrowanych wokół zasług magnatki dla ojczyzny. Nieznany twórca przypisał solenizantce umiłowanie rodzinnych stron na miarę tego, które niegdyś cechowało heroiny „i Sparty, i Rzymu” (w. 15). Wskazał ponadto, że jej cnoty stanowią także „duch obywatelski, patriotyzm szczyry” (w. 16). Za potwierdzenie wysokiej rangi dokonań księżny dla kraju uznał publiczną działalność jej syna. Według autora „duch cnoty” (w. 17) oraz rozum kierowały bowiem wychowaniem młodego księcia, który - jak dowiódł ostatni sejm - dojrzał do sprawowania zaszczytnej funkcji posła. Uzasadnienie „warsztatowego”, a przede wszystkim moralnego przygotowania arystokraty do wypełniania związanych z tym obowiązków stanowi dar wymowy. Wykorzystując go w trakcie obrad, książę „czynił serc odmiany" (w. 29), zdołał bowiem nakłonić sejmujących do zgody ${ }^{19}$. W przekonaniu twórcy tym dokonaniem Sapieha nawiązał do zaszczytnych osiągnięć Franciszka Stefana Sapiehy z różańskiej linii rodu, koniuszego litewskiego i marszałka sejmu grodzieńskiego, który odbył się na przełomie lat $1678-1679^{20}$, przechodząc do historii jako pierwsze zgromadzenie zwołane w tym mieście po zawiązaniu unii lubelskiej, co autor skrupulatnie odnotował ${ }^{21}$. Ponadto zalety i zasługi arystokra-

${ }^{18}$ B. Mazurkowa, Problem i przejawy panegiryzmu w poezji okolicznościowej drugiej połowy XVIII wieku, w: Panegiryk jako element życia literackiego doby staropolskiej i oświeceniowej, red. M. Sulejewicz-Nowicka, Z. Gruszka, wstęp M. Wichowa, Wydawnictwo Uniwersytetu Lódzkiego, Łódź 2013, s. 268-269.

${ }^{19}$ Komplementy odwołujące się do publicznej działalności Kazimierza Nestora Sapiehy, zgodnie chwalonej przez posłów, dotyczą zapewne jego deklaracji podarowania armii litewskiej dwunastu armat. Należy jednak pamiętać, że arystokrata działał wówczas nie tylko na rzecz porozumienia sejmujących. Pozostawał w opozycji do stronnictwa królewskiego, a dążąc do sparaliżowania zamierzeń regalistów, groził nawet zerwaniem obrad. Zob. Ł. Kądziela, Sapieha Kazimierz Nestor..., s. 54.

${ }^{20}$ A. Rachuba, Sapieha Franciszek Stefan, w: PSB, t. 34, Wrocław 1992-1993, s. 603; zob. także drzewo genealogiczne (tablica 2) dołączone do monografii: E. Sapieha, M. Kałamajska-Saeed, Dom Sapieżyński, cz. 2: Ikonografia, Wydawnictwo Naukowe PWN, Warszawa 2008.

${ }^{21}$ Chronologia sejmów..., s. 157 [31] (poz. 180). 
ty są w pochwalnym ujęciu źródłem szczęścia matki, miłości obywateli, dumy mieszkańców Pren oraz słusznej sławy jego samego. Elementy laudacyjnego wizerunku, określające Sapieżynę jako patriotkę sposobiącą syna do działalności publicznej w duchu poszanowania rodzimych tradycji, wpisują ów konterfekt w nurt ujęć, które stały się szczególnie popularne od czasu pierwszego rozbioru. Wtedy to bowiem - w związku z dramatyczną sytuacją kraju - konieczne stało się inne niż dotąd postrzeganie roli kobiet. W sposób szczególny dotyczyło to upowszechniania dobrych obyczajów i postaw korzystnych dla wspólnoty. $Z$ tego też powodu, zarówno w ujęciach literackich, jak i na scenie publicznej arystokratki coraz częściej występowały wówczas jako przykładne matrony, które kształtują i krzewią postawy patriotyczne w gronie członków własnych rodzin oraz wśród współobywateli ${ }^{22}$. W omawianym utworze wskazana tendencja znalazła wyraz w wyeksponowaniu walorów duchowych, siły rozumu, obywatelskiej postawy i patriotyzmu księżny, a także w podkreśleniu zarówno jej wpływu na chwalebną działalność publiczną syna, jak i szacunku oraz wdzięczności preńskich obywateli. Laudacyjny wiersz zamykają: skierowana do solenizantki prośba o życzliwe przyjęcie imieninowego daru oraz życzenia wielu lat życia ku pożytkowi rodziny, sług i ojczyzny.

Wskazane w utworze przejawy czy też poświadczenia wielkości Sapieżyny, a nadto zaszczytne przymioty wojewodzicowej oraz głośne osiągnięcia generała artylerii litewskiej zostały nazwane $\mathrm{w}$ wierszu bukietami ofiarowanymi arystokratce z okazji dorocznego święta, ale też na okoliczność powitania jej w Prenach. Taki zamysł nawiązuje do popularnego wówczas motywu stosowanego w utworach imieninowych i urodzinowych. Wiersze pisane na doroczne święta często określano metaforycznie właśnie mianem bukietów, a splecione były nie z żywych kwiatów, lecz ze szlachetnych przymiotów, zalet, cnót oraz zasług solenizantów ${ }^{23}$. Analogiczne są też funkcje i pochodzenie tych okolicznościowych podarunków dla magnatki - to należne jej z racji osobistych walorów „serc i dusz daniny” (w. 11), a także bez wątpienia miły dla niej hołd złożony sławie jedynaka. Ten drugi aspekt laudacji dodatkowo eksponuje obywatelskie i patriotyczne rysy portretu wojewo-

${ }^{22}$ M. Chachaj, Postać kobiety-Polki w dramatach historycznych Juliana Ursyna Niemcewicza, „Annales Universitatis Mariae Curie-Skłodowska. Sectio FF: Philologiae” 1999, vol. 17, s. 96-102. Jednym z najgłośniejszych poświadczeń rozwijania w sferze publicznej nowej roli kobiet w Polsce stanisławowskiej było wystawienie 15 czerwca 1786 roku w Puławach, inspirowanej przez Izabelę Czartoryską opery Matka Spartanka Franciszka Dionizego Kniaźnina. Zob. M. Toczyńska, Spartanka i Cyganka w teatrze Franciszka Dionizego Kniaźnina, w: Kobieta epok dawnych w literaturze, kulturze i społeczeństwie, red. I. Maciejewska, K. Stasiewicz, Wydawnictwo Littera, Olsztyn 2008, s. 130-138; R. Kaleta, ,Spartanka”. Nieznany poemat Stanisława Trembeckiego. Przyczynek do sporu politycznego oligarchów z królem Stanisławem Augustem, w: tegoż, Oświeceni i sentymentalni..., s. 413-442. Por. także: T. Kostkiewiczowa, Kobiety w liryce Kniaźnina, w: Kobieta epok dawnych..., s. 81-85, 88.

${ }^{23}$ Zob. rozważania poświęcone wyznacznikom poetyckich bukietów oraz konkretnym utworom realizującym ten wzorzec poezji okolicznościowo-podarunkowej: B. Wolska, B. Mazurkowa, T. Chachulski, Oświeceniowa poezja imieninowa ..., s. 20-25, 39-53. 
dzicowej. Nawiązania do poetyki bukietu nie oznaczają jednak, że utwór należy rozpatrywać wyłącznie w ramach jednego gatunku poetyckiego. Podniosły styl, liczne inwersje i wykrzyknienia oraz konsekwentnie utrzymany tok apostroficzny sprawiają, że wiersz ten ma charakter wiązanej rymami przemowy wygłaszanej w imieniu milczącej zbiorowości, co sytuuje to powinszowanie w kręgu wysokiej ody okolicznościowej ${ }^{24}$. Należy również stwierdzić, że do upatrywania w tym tekście realizacji wyznaczników panegiryku skłania kilka ważnych cech, takich jak: wykreowana w wierszu aura powszechnego hołdu preńskiej społeczności dla osobistych zalet księżny, pośrednie wskazanie walorów posiadanych przez arystokratkę z racji urodzenia i małżeństwa, bardzo pochlebna ocena de facto szkodliwej postawy księcia w czasie sejmu grodzieńskiego ${ }^{25}$, a także wyraźnie instrumentalne traktowanie problematyki patriotycznej i obywatelskiejej.

Podobnie nacechowany jest również kolejny utwór poświęcony Sapieżynie - opatrzony obszerną formułą tytułową, która określa go jako Ofiarę serc obywatelskich narodu polskiego i W[ielkiego] Ks[ięstwa] Lit[ewskiego]... ${ }^{27}$, uczynioną rodowi Sapiehów z okazji przybycia do Warszawy brata księżny Franciszka Ksawerego Branickiego, hetmana wielkiego koronnego i przywódcy własnego stronnictwa politycznego, a także w związku z objęciem przez Kazimierza Nestora Sapiehę funkcji marszałka niedawno zawiązanej konfederacji sejmowej. Druk ten - choć został odnotowany zarówno przez kompendium Estreicherów, jak i bibliografię „Nowy Korbut” - nie doczekał się komentarzy ze strony badaczy, być może ze względu na fakt, iż jego autor Wojciech Zacharkiewicz, rejent ziemski

${ }^{24}$ T. Kostkiewiczowa, Oda, w: Słownik literatury polskiego oświecenia, red. taż, wyd. 4, Zakład Narodowy im. Ossolińskich - Wydawnictwo, Wrocław 2006, s. 324-326.

${ }^{25}$ Warto odnotować, że w rozmowie, która odbyła się 16 czerwca 1788 roku w Łazienkach, Stanisław August Poniatowski skarżył się Sapieżynie na zachowanie i oporną postawę jej syna wobec zamierzeń obozu królewskiego między innymi właśnie w czasie sejmu grodzieńskiego. Odręczny zapis dialogu zachował się w Bibliotece Książąt Czartoryskich w Krakowie, rkps 931, s. 449-453.

${ }^{26}$ J. Platt, Panegiryk, w: Słownik literatury polskiego oświecenia..., s. 391-395; B. Mazurkowa, Problem i przejawy panegiryzmu..., s. 255-274; B. Wolska, Ogólne uwagi o twórczości okolicznościowej Adama Naruszewicza..., s. 123-174; tejże, Poezja pochwalna i panegiryczna Adama Naruszewicza. Pochwały władcy, w: Byle w ludziach światło było... Księga pamiatkowa ku czci Profesora Wacława Woźnowskiego w dziesiąta rocznice jego śmierci, red. G. Zając, Księgarnia Akademicka, Kraków 2012, s. 359-376, Studia Dziewiętnastowieczne. Rozprawy, t. 10; tejże, Poezja pochwalna i panegiryczna Adama Naruszewicza. Pochwaty osobistości publicznych i osób prywatnych, w: Panegiryk jako element życia literackiego..., s. 165-205.

${ }^{27}$ W. Z[acharkiewicz], Ofiara serc obywatelskich narodu polskiego i W[ielkiego] Ks[ięstwa] Lit[ewskiego] Jaśnie Oświeconej familii książat Ichmościów Sapiehów z okoliczności przyjazdu na sejm do Warszawy Jaśnie Wielmożnego Branickiego, hetmana wielkiego koronnego, i marszałkostwa sejmowego Jaśnie Oświeconego ks[ię]cia Jmci Sapiehy, generała artylerii lit[ewskiej], Jaśnie Oświeconej księżnej Jejmości El<ż>biety Sapieżyny syna, a Jaśnie Wielmożnego hetmana siostrzeńca, w miesiącu grudniu roku 1788 przez wdzięcznego tej famili<i> patriote uczyniona, [Warszawa 1788], s. 1-7, Biblioteka Uniwersytecka w Warszawie, sygn. 4.20.1.557. Utwór cytowany jest według podanej edycji. 
brzeskokujawski, nie należał do grona wpływowych ani utalentowanych literatów ${ }^{28}$. Okres jego działalności twórczej zamyka się w latach 1788-1793, kiedy opublikował dziewięć pochwalnych wierszy skierowanych do różnych osób oraz dwa teksty publicystyczne ${ }^{29}$. Ofiara serc obywatelskich... jest pierwszym znanym utworem Zacharkiewicza.

Pod rozbudowanym tytułem skrywa się niewielki cykl wierszy pochwalnych, w którym każdy z utworów ma innego adresata, indywidualnego bądź zbiorowego. Pierwszy utwór skierowany jest do Franciszka Ksawerego Branickiego, następny - do Elżbiety Sapieżyny, trzeci - do Kazimierza Nestora Sapiehy, natomiast czwarty i zarazem ostatni - do całej trójki. Okoliczności powstania tego zbioru, ogólnie wskazane w nadrzędnej formule tytułowej, konkretyzuje początkowy fragment pierwszego tekstu:

Dzień ten wesoły i nader nam miły, W który hetmana nieba sprowadziły

Do tej stolicy na obrady święte.

O! Jak języki złych będą cofnięte,

Które zaoczne już zdania dawały,

Jakby go nigdy oglądać nie miały.

Patrzcież na niego, wszak ten niezmieniony,

Mówcie, czy ganny, czy ma być wielbiony?

(Do Jaśnie Wielmożnego hetmana w[ielkiego] kor[onnego], w. 1-8)

Nawiązując do przybycia magnata do Warszawy 17 grudnia $1788 \mathrm{roku}^{30}$, Zacharkiewicz skomponował zwięzłą deskrypcję. Niewątpliwie pochlebny wy-

${ }^{28}$ K. Estreicher, Bibliografia polska, cz. 3: Stulecie XV-XVIII w układzie abecadłowym, t. 23 (34), z. 1: Z-Załuski, do druku przygotował K. Estreicher, Akademia Umiejętności, Kraków 1951, s. 61-63; Bibliografia literatury polskiej „Nowy Korbut”, [t.] 6, cz. 1: Oświecenie. Hasła osobowe $P-\dot{Z}$. Addenda A-O, oprac. E. Aleksandrowska z zespołem, red. tomu do r. 1958 T. Mikulski, Państwowy Instytut Wydawniczy, [Warszawa] 1970, s. 510; [t.] 6, cz. 2: Oświecenie. Uzupetnienia, indeksy, oprac. E. Aleksandrowska z zespołem, Państwowy Instytut Wydawniczy, [Warszawa] 1972, s. 143.

${ }^{29} \mathrm{Na}$ temat publicystyki Zacharkiewicza zob. zwięzłe uwagi Anny Grześkowiak-Krwawicz w książce: O formę rządu czy o rząd dusz? Publicystyka polityczna Sejmu Czteroletniego, Instytut Badań Literackich PAN Wydawnictwo, Warszawa 2000, s. 21, 48, 292-293, 310, 358, 359-360, 373. Zob. również: K. Maksimowicz, Poezja polityczna..., s. 43, 44. Ponadto cztery spośród panegiryków rejenta zostały opublikowane w edycjach: Wiersze polityczne Sejmu Czteroletniego, cz. 1: 1788-1789, z papierów E. Rabowicza oprac. K. Maksimowicz, Wydawnictwo Sejmowe, Warszawa 1998, s. 301-307; cz. 2: 1790-1792, Warszawa 2000, s. 92-95, 204-207; Wiersze polityczne czasu konfederacji targowickiej i sejmu grodzieńskiego 1793 roku, oprac. K. Maksimowicz, Wydawnictwo Uniwersytetu Gdańskiego, Gdańsk 2008, s. 442-443.

${ }^{30}$ Informacja na temat przyjazdu arystokraty otwiera 102 numer „Gazety Warszawskiej” z soboty 20 grudnia 1788 roku (k. [1]r), co pośrednio świadczy o pewnym zainteresowaniu opinii 
dźwięk opisu „dnia wesołego” jest wynikiem wprowadzonych określeń pośrednio wskazujących radosne reakcje obywateli na powrót hetmana do stolicy. Poszerzając tę perspektywę, autor poświęcił uwagę przewidywanej ocenie tego wydarzenia przez część opinii publicznej najwyraźniej krytycznie odnoszącej się do poczynań Branickiego. Scharakteryzowanie środowiska przeciwników hetmana słowami: ,języki złych [...], / Które zaoczne już zdania dawały” (w. 4-5), skłania do wniosku, że pobudką do napisania pochwalnego utworu była chęć odparcia zarzutów wysuwanych w początkowym okresie obrad wobec hetmana. Brat wojewodzicowej stanął w Warszawie ponad dwa miesiące po rozpoczęciu sejmu, co nastąpiło - jak wiadomo - 6 października ${ }^{31}$. Wcześniej, od końca kwietnia, Branicki przebywał w otoczeniu swego rosyjskiego protektora Gregorija Potiomkina, najpierw na zjeździe w Elizabetgradzie, a potem pod Oczakowem, dobrze ufortyfikowaną twierdzą osmańską nieopodal ujścia Dniepru ${ }^{32}$. Przyczyny oburzenia w stolicy postępowaniem polskiego arystokraty były zatem oczywiste - oto najwyższy zwierzchnik armii Korony w czasie gdy toczyły się obrady sejmu, a więc w okresie szczególnie ważnym dla ojczyzny, zamiast włączyć się do debat, służyć radą, towarzyszył głównodowodzącemu wojsk carskich na obcej wojnie. Negatywny rezonans poczynań hetmana dodatkowo wzmacniały antyrosyjskie nastroje panujące na początku czteroletniego zgromadzenia ${ }^{33}$. Wszystko to - jak należy wnioskować z przytoczonego fragmentu wiersza - spowodowało rozpowszechnianie przez oponentów magnata złośliwych zapowiedzi, że Branicki w ogóle nie przybędzie na obrady. Jakby tego było mało, przedłużający się pobyt hetmana pod Oczakowem został skrytykowany w trakcie jednego z posiedzeń posłów i senatorów przez Michała Jerzego Poniatowskiego, prymasa i przywódcę stronnictwa regalistycznego ${ }^{34}$. Ze względu na wskazane okoliczności skierowany do magnata utwór Zacharkiewicza należy odczytać jako próbę odpowiedzi na ataki wymierzone w arystokratę. Możliwe zatem, że pomysł na ten wiersz wyszedł albo od samej Sapieżyny, albo z kręgów zbliżonych do księżny lub jej syna, na co wskazywałyby zapisy w formule tytułowej cyklu, podkreślające przywiązanie autora do litewskiego rodu.

publicznej jego poczynaniami. Jak zwięźle poinformowano: „Jmć pan Branicki, hetman w[ielki] kor[onny] w przeszłą środę do tutejszej przybył stolicy".

${ }^{31}$ Chronologia sejmów..., s. 169 [43] (poz. 244).

${ }^{32} \mathrm{O}$ wpływach i przedsejmowych poczynaniach Branickiego i jego partii w Polsce oraz na Litwie zob. J. Michalski, Sejmiki poselskie 1788 roku, „Przegląd Historyczny” 1960, t. 51, z. 1, s. 52, 62-63; tegoż, Sejmiki poselskie 1788 r. (cz. II), „Przegląd Historyczny” 1960, t. 51, z. 2, s. 337-338, 344-345, 356. Por. także ustalenia Waleriana Kalinki dotyczące upadku Oczakowa, a także działań hetmana w okresie przygotowań do sejmowych obrad, jak się później okazało - czteroletnich, jak również w pierwszych miesiącach poselskich debat: Sejm Czteroletni, t. 1, przedm. Z. Zielińska, Oficyna Wydawnicza Volumen, Warszawa 1991, zwłaszcza s. 38-45, 64-66, 96-100.

${ }^{33}$ K. Maksimowicz, Poezja polityczna..., s. 18-26.

${ }^{34}$ W. Kalinka, Sejm Czteroletni..., s. 164-166. 
Poza wskazaniem, że złośliwe plotki na temat Branickiego będą musiały ucichnąć, w pierwszej części cyklu Zacharkiewicz zaprezentował utrzymaną w pochwalnym tonie sylwetkę hetmana. Portret arystokraty współtworzą wysoko cenione, lecz dość ogólnie nazwane w wierszu walory typowe dla wzorcowego dowódcy wojska - cnotliwość, waleczność, wierność wyznawanym wartościom, znajomość własnych możliwości, zaufanie ludziom, przywiązanie do ojczyzny oraz wroga postawa wobec jej zdrajców. Dopełnieniem portretu Branickiego są zamieszczone w następnych częściach cyklu pochlebne wizerunki poetyckie jego siostry i siostrzeńca.

Drugi utwór okolicznościowego cyklu, podobnie jak wiersz imieninowy z 1784 roku, sytuuję Sapieżynę w kręgu ideałów patriotycznych i obywatelskich, lecz pochwalny wydźwięk laudacji jest tu - z wielu powodów - znacznie silniejszy. Oba teksty na cześć wojewodzicowej łączy podkreślana w nich podniosła aura powszechnego hołdu, lecz w przypadku portretu zarysowanego przez Zacharkiewicza zbiorowością zachwyconą cnotami arystokratki jest nie tylko lokalna społeczność - tworzą ją obywatele reprezentujący całą Rzeczypospolitą:

Stawiamy-ć, księżno, już w sercach ołtarze, W nich brat i z synem niech chwaleni w parze

Będą od wszystkich, niech cię wielbią ziemie Za dobre plemię.

(Do Jaśnie Oświeconej księżnej Jejmci Sapieżyny, w. 1-4)

W przytoczonym fragmencie „plemię” oznacza potomstwo (a zatem syna Kazimierza Nestora), a także ród - jak można wnioskować na podstawie następnej strofy, która zawiera pochwałę narodzin „W przezacnym pr<z>odków starożytnym domu" (w. 6). Sapieżyna jest więc bezpośrednio komplementowana z racji wydania na świat, a następnie odpowiedniego wychowania patrioty i utalentowanego mówcy z domu Sapiehów, jak również ze względu na zaszczyt przynależności do Branickich herbu Korczak i na bliskie pokrewieństwo z hetmanem, który w pierwszej części cyklu został ukazany jako wielki wódz i patriota. Tradycyjnemu wywyższeniu znaczenia paranteli towarzyszy w laudacji niemal natrętne podkreślanie nadzwyczajnych walorów księżny. Owa „ziemska bogini” (w. 10) - by posłużyć się określeniem autora - posiada „rozum męski” (w. 30), ponadto odznacza ją „wielka dusza" (w. 32), które to przymioty mogą być zaskakujące dla osób stykających się z arystokratką. Takie same zalety wskazał również preński panegirysta, lecz Zacharkiewicz uderzył w znacznie wyższy ton, co przybrało najbardziej wyrazisty kształt w odwołaniu do wysoko cenionej tradycji obywatelskiej Rzymu ${ }^{35}$ :

${ }^{35}$ Zob. A. Grześkowiak-Krwawicz, Polska myśl polityczna epoki Oświecenia wobec tradycji antycznej, w: Antyk oświeconych. Studia i rozprawy o miejscu starożytności w kulturze pol- 
U Rzymian z cnót, dzieł tę nadgrodę miano,

Że ich ojczyzny ojców nazywano,

Ale któż tobie tytuł doskonały

Znajdzie dla chwały?

Ty Polskę szczycisz krwią i twymi czyny,

Przewyższasz sercem wielkie heroiny,

Bądźże więc, z syna i z dzieł twoich rzadka,

Ojczyzny matka.

(Do Jaśnie Oświeconej księżnej Jejmci Sapieżyny, w. 37-44)

Zastanawiając się nad tytułem właściwym dla osoby tak niezwykle cnotliwej i zasłużonej jak Sapieżyna, poeta nawiązał do zaszczytnej formuły Mater Patriae, o którą za czasów cesarza Tyberiusza bezskutecznie zabiegała jego matka Liwia Druzylla $^{36}$. Przytoczony fragment wiersza stanowi kulminacyjną część laudacji, trudno bowiem o bardziej jednoznaczne usytuowanie księżny w kręgu najwyższych cnót patriotycznych, a także przedstawienie jej jako niedościgłego wzoru obywatelskiego postępowania. Stąd w końcowej partii utworu, po złożeniu adresatce życzeń długich lat życia, autor, wykorzystując popularny topos laudacyjny, kilkukrotnie zapewnił o niemożliwości pełnego ujęcia wszystkich zalet i zasług magnatki. Wszystkie wskazane ujęcia powodują, że księżna została w okolicznościowej wypowiedzi wręcz ubóstwiona.

Z kolei w poświęconym Kazimierzowi Nestorowi Sapieże trzecim utworze cyklu adresat przedstawiony jest jako niezrównany mówca, co - nie bez podstaw - często podkreślano w laudacyjnych portretach księcia z czasów Sejmu Wielkiego $^{37}$. Autor uwypuklił, że syn wojewodzicowej to powszechnie uwielbiany statysta, którego sława sięgająca poza granice ojczyzny (Do Jaśnie Oświeconego księcia Jmci Sapiehy, marszatka sejmowego, siostrzeńca i syna, w. 1-2) przyćmiewa pamięć o zaszczytnych osiągnięciach „naddziadów” (w. 2) arystokraty - Lwa Bazylego Sapiehy, kanclerza, a następnie hetmana wielkiego litewskiego, oraz Pawła Jana Sapiehy, również hetmana wielkiego litewskiego. Obaj należeli do grona najbardziej znanych przedstawicieli potężnej familii i słynęli z wieloletniej działalności publicznej, chociaż w zasadzie nie są przodkami generała arty-

skiej XVIII wieku, red. T. Chachulski, Instytut Badań Literackich PAN Wydawnictwo, Warszawa 2012, s. 75-80.

${ }^{36}$ A. Krawczuk, Poczet cesarzy rzymskich. Pryncypat, Iskry, Warszawa 1986, s. 39.

${ }^{37} \mathrm{~W}$ trakcie czteroletnich obrad sejmowych książę miał przemawiać łącznie siedemset sześćdziesiąt razy. Ł. Kądziela, Sapieha Kazimierz Nestor..., s. 55, 65. Zob. także: K. Maksimowicz, Poezja polityczna..., zwłaszcza s. 88, 91, 108; D. Rolnik, Sapiehowie czasów stanisławowskich (1764-1795) na kartach pamiętników polskich. O roli i znaczeniu rodu u schytku istnienia Pierwszej Rzeczypospolitej, w: Sapiehowie epoki Kodnia i Krasiczyna, red. K. Stępnik, Wydawnictwo Uniwersytetu Marii Curie-Skłodowskiej, Lublin 2007, s. 478-479. 
lerii litewskiej, reprezentowali bowiem różańską gałąź rodu, w przeciwieństwie do księcia, który był przedstawicielem Sapiehów kodeńskich ${ }^{38}$.

Warto odnotować, iż różnice między portretami wykreowanymi przez Zacharkiewicza nie ograniczają się do doboru cech - ze zrozumiałych względów - odmiennych w portretach postaci odgrywających różne role na scenie publicznej. Rozbieżności są głębsze, a ich kształt wyznacza - by tak rzec - granica płci. Mężczyźni są tu zarówno adresatami pochwał, jak i pewnych oczekiwań oraz nadziei, którym - jako czynni politycy - powinni sprostać, o czym zapewnia czytelników autor wierszy, projektując opis przyszłego postępowania Branickiego i Sapiehy. Ponadto w pierwszej, a w szczególności w trzeciej części pochwalnego cyklu zawarte są wyraźnie sformułowane wezwania, aby obaj dostojnicy podjęli starania zmierzające do odzyskania ziem zagarniętych w czasie pierwszego rozbioru. Postulat ten nie może zaskakiwać u pisarza związanego z województwem brzeskokujawskim. Natomiast w drugim utworze cyklu Sapieżyna została wykreowana na uosobienie wzoru cnót obywatelskich i patriotycznych, który winien być pobudką do dobrego postępowania współobywateli i zarazem powodem pełnego, aczkolwiek biernego uwielbienia wojewodzicowej. Niczego się tu jednak od księżny nie oczekuje, arystokratka nie stała się również źródłem pochwał w utworach poświęconych jej krewnym, chociaż zarówno syn, jak i brat magnatki zostali przywołani już w pierwszej strofie wiersza na jej cześć.

Zamykając portretowy cykl czwartym utworem, Zacharkiewicz skomponował ostatnią wiązankę komplementów. Nazywał troje spokrewnionych ze sobą polityków „ozdobą i światłem ojczyzny” (Do wszystkich razem, brata i siostry, wuja $i$ matki, siostr $<z>$ eńca $i$ syna, w. 4), a także stwierdził: „,Jedna życia nadzieja, że się na was wspiera. / Wy dzielnością wzruszycie zwycięzców popioły, / Wam śpiewać będą chwały z narodem kościoły" (w. 6-8). Poeta dopełnił tym samym pochwałę zapewnieniami o nieprzemijającej sławie zalet i zasług księżny oraz jej najbliższych krewnych, a także - na końcu - poprosił o łaskawą pamięć o twórcy okolicznościowych powinszowań.

Podniosła atmosfera „obywatelskiego” hołdu, tradycyjne podkreślanie znaczenia rodu i koligacji, wyjątkowo wysoka ocena walorów osobistych (nie zawsze w sposób uzasadniony sytuowanych w kręgu ideałów patriotycznych), wiązanie zbyt optymistycznych, by nie rzec, naiwnych nadziei z politycznymi planami Branickiego, a w przypadku drugiego portretu - wręcz ubóstwienie księżny jako matki ojczyzny, naznaczają wiersze Zacharkiewicza wyraźnym piętnem panegiryzmu. Ten poetycki cykl składa się z portretów trzech najważniejszych postaci ówczesnego stronnictwa hetmańskiego, przekazując bardzo pochlebną wizję kompetentnego i dzielnego wodza, zacnej i mądrej matrony, a także sławnego mówcy i mar-

${ }^{38}$ Zob. drzewa genealogiczne (tablice 1-2, 4) zamieszczone w tomie: E. Sapieha, M. Kałamajska-Saeed, Dom Sapieżyński, cz. 2... 
szałka - połączonych nie tylko więzami krwi, lecz również wspólnymi ideałami. Można przypuszczać, że to ujęcie nie stanowiło oryginalnego pomysłu Zacharkiewicza, lecz raczej utrwalało wcześniej powstałe sądy na temat powiązań pomiędzy chwalonymi arystokratami, potwierdzone wieloletnimi działaniami politycznymi. Równocześnie dobór adresatów i kompozycja zbioru być może były również związane ze świadomym zamysłem propagandowym, który zrodził się w początkach Sejmu Wielkiego w stronnictwie Branickiego. Stąd nie bez przyczyny Franciszek Zabłocki zastanawiał się $\mathrm{w}$ jednym $\mathrm{z}$ paszkwili napisanych $\mathrm{w}$ drugiej połowie 1789 roku: „Sapieżyno! wasz związek z twym synem i bratem, / Nie wiem, za co, lecz wszyscy zwą triumwiratem" (w. 11-12) ${ }^{39}$. Deklarowana przez poetę niewiedza na temat powodów stosowania wskazanej nazwy niewątpliwie była pozorowana, a przyznanie się do niej zostało wprowadzone w celu czytelnego nawiązania do znanego, również z utworu Zacharkiewicza, ujęcia, a następnie do jego zdyskredytowania i - na końcu - ośmieszenia wojewodzicowej.

Omówione utwory, jakkolwiek są interesującymi przykładami okolicznościowych powinszowań, bez wątpienia nie należą do dzieł wybitnych. Nie ma tu - jak na przykład w pochwalnych wierszach Adama Naruszewicza - próby wyjścia poza konieczność złożenia hołdu należnego patronowi i wprowadzenia refleksji na temat zjawisk, procesów i powinności związanych z funkcjonowaniem wspólnoty; rozważań, które w mniejszym lub większym stopniu zacierały okolicznościowy charakter liryków ${ }^{40}$. Oczywiście, zarówno nieznany twórca preńskiej ody, jak i Wojciech Zacharkiewicz, komponując laudację, odwołali się do pewnych wartości niezwykle ważnych dla zbiorowości, lecz nie po to, aby powiedzieć coś o adresatach wierszy lub o rozważanych ideałach, lecz wyłącznie w celu usytuowania patronów w pochlebnym kontekście tych powszechnie przyjętych wzorów i wysoko cenionych zalet. Przesądza to o klientalnym charakterze omawianych wierszy, które mimo wyraźnych znamion interesowności autorów, pozwalają choć w niewielkim stopniu zrównoważyć rozpowszechnione wśród historyków literatury opinie, że Elżbieta Sapieżyna spotykała się z wyjątkową - jak na swoje czasy - niechęcią.

\section{Bibliografia}

\section{Podmiotowa}

Chądzyński Antoni, Oda w dzień imienin Jaśnie Oświeconej księżnej Jejmości Elżbiety Sapieżyny, wojewodziny mścisławskiej, ofiarowana od... kapitana gwardii pieszej koronnej, dnia 19 listopada 1788, k. nlb. 2, Warszawa [1788], Biblioteka Instytutu Badań Literackich PAN, sygn. XVIII.2.534.

${ }^{39}$ F. Zabłocki, Triumwirat, w: tegoż, Pisma, zebrał i wyd. B. Erzepki, Poznań 1903, s. 191.

${ }^{40}$ Zob. przywołane w przypisach 8 i 26 prace Barbary Wolskiej na temat liryków nadwornego poety Stanisława Augusta. 
Do Jaśnie Oświeconej księżnej Jejmości Elżbiety z Branickich Sapieżyny, wojewodzicowej $m<\dot{s}>c i$ sławskiej, w dzień imienin 19 Novembris 1784 w Prenach, [b.m.] [1784], k. nlb. 2, Biblioteka Narodowa, sygn. XVIII 2.7049.

„Gazeta Warszawska” 1788, nr 102 (20 grudnia).

Gurowski Rafał, Na dzień imienin jednej z J[aśnie] W[ielmożnych] Elżbiet w Warszawie, w: tegoż, „Zbiór różnych rytmów...” oraz pism, s. 505, Zakład Narodowy im. Ossolińskich, rkps $14262 /$ III.

Gurowski Rafał, Respons w obronie pięciu Elżbiet..., w: tegoż, „Zbiór różnych rytmów...” oraz pism, s. 448-449, Zakład Narodowy im. Ossolińskich, rkps 14262/III.

Kościałkowski Kajetan, Oda do J[aśnie] O[świeconej] księżny Jejmci Sapieżyny, wojewodzicowej mścisławskiej z okoliczności jej imienin przypadtych dnia 19 Novembra w dzień ś[więtej] Elżbiety, „Muza Ukryta pod Znakiem Herbu Syrokomli” 1773, t. 1, tydzień 2, k. [7], Biblioteka Jagiellońska, sygn. 931/I.

Kościałkowski Kajetan, Wiersz z okoliczności fajerwerku i balu wyprawionego dla J[aśnie] O[świeconych] i J[aśnie] W[ielmożnych] Elżbiet kosztem J[aśnie] W[ielmożnego] Jmc[i] pana hetmana polnego koronnego, dnia 18 Novembra w Warszawie, „Muza Ukryta pod Znakiem Herbu Syrokomli" 1773, t. 1, tydzień 3, k. [9], Biblioteka Jagiellońska, sygn. 931/I.

Naruszewicz Adam, Powinszowanie księżnie Elżbiecie z Branickich Sapieżyn<ie> szczęśliwego do zdrowia powrócenia, w: tegoż, Poezje zebrane, t. 1, wyd. B. Wolska, Instytut Badań Literackich PAN Wydawnictwo - Akademia Humanistyczna, Warszawa 2005, s. 170-172 (utwór), 231 (koment. edyt.), 312-313 (objaśn.), Biblioteka Pisarzy Polskiego Oświecenia, t. 4.

Oda do ojczyzny na dzień 19 listopada $w$ roku 1774, w: Wiersze polityczne pierwszego rozbioru i sejmu delegacyjnego 1772-1775, oprac. B. Wolska, Wydawnictwo Sejmowe, Warszawa 2001, s. 293-297 (utwór i objaśn.).

Sapieżyna Elżbieta z Branickich do Okęckiego Antoniego Onufrego, Olita, 18 listopada 1784, w: Korrespondenz der Fürsten Sapieha. 1709-1798, Archiwum Główne Akt Dawnych, Archiwum Komierowskich, rkps 12/12, s. 173-177.

Tyszkowski Wenanty, Jaśnie Oświeconej księżnie Jmci Elżbiecie z Branickich księżnie Sapieżynie, wojewodzicowej mścisławskiej, pani i dobrodzice, w: tegoż, Teatrum myśli albo zdań z soba walczacych $w$ materiach siłu rozróżnionych religii szukającym prawdy otworzone, przez siedmiu aktorów zagajone. Tomik o miejscach osobliwych razem z światem calym stworzonych do ukarania wszystkich grzesznych, od samegoż Stwórcy wyznaczonych, Drukarnia Bractwa Św[iętej] Trójcy, Lwów 1780, k. $\mathrm{A}_{2} \mathrm{r}-\left[\mathrm{A}_{4}\right] \mathrm{v}$.

Z[acharkiewicz] W[ojciech], Ofiara serc obywatelskich narodu polskiego i W[ielkiego] Ks_ięstwa] Lit[ewskiego] Jaśnie Oświeconej familii książąt Ichmościów Sapiehów z okoliczności przyjazdu na sejm do Warszawy Jaśnie Wielmożnego Branickiego, hetmana wielkiego koronnego, i marszałkostwa sejmowego Jaśnie Oświeconego ks[ię]cia Jmci Sapiehy, generata artylerii lit_ewskiej], Jaśnie Oświeconej księżnej Jejmości El<ż>biety Sapieżyny syna, a Jaśnie Wielmożnego hetmana siostrzeńca, w miesiącu grudniu roku 1788 przez wdzięcznego tej famili< $i>$ patriote uczyniona, [Warszawa 1788], s. 1-7, Biblioteka Uniwersytecka w Warszawie, sygn. 4.20.1.557.

\section{Przedmiotowa}

Aleksandrowska Elżbieta, Kościałkowski Kajetan, w: Polski Słownik Biograficzny, t. 14, Wrocław 1968-1969, s. 391-392.

Chachaj Małgorzata, Postać kobiety-Polki w dramatach historycznych Juliana Ursyna Niemcewi$c z a$, ,Annales Universitatis Mariae Curie-Skłodowska. Sectio FF: Philologiae” 1999, vol. 17, s. $95-113$.

Czeppe Maria, Sapieżyna z Branickich Elżbieta, w: Polski słownik biograficzny, t. 35, Warszawa 1994, s. 163-167.

Dąbrowski Szymon Piotr, Portrety Elżbiety z Branickich Sapieżyny w paszkwilach obyczajowych i politycznych, w: Codzienność i niecodzienność oświeconych, [cz.] 2: Wrezydencji, w podró- 
ży i na scenie publicznej, red. B. Mazurkowa, z udziałem M. Marcinkowskiej i S. P. Dąbrowskiego, Wydawnictwo Uniwersytetu Śląskiego, Katowice 2013, s. 139-152, Prace Naukowe Uniwersytetu Śląskiego w Katowicach, nr 3072.

Dąbrowski Szymon Piotr, Uwagi o „Porankach kodeńskich” Ignacego Potockiego, „Wschodni Rocznik Humanistyczny" 2014, t. 10, s. 189-198.

Dąbrowski Szymon Piotr, Wizja przestrzeni eschatologicznych w „,Teatrum myśli...” Wenantego Tyszkowskiego, w: Światy oświeconych i romantycznych. Doświadczenia, uczucia, wyobraźnia, red. B. Mazurkowa, Wydawnictwo Uniwersytetu Śląskiego, Katowice 2015, s. 155-175, Prace Naukowe Uniwersytetu Śląskiego w Katowicach, nr 3343.

Gomulicki Juliusz Wiktor, Młody „gniewny” polskiego oświecenia, w: [T.]K. Węgierski, Wiersze wybrane, wybrał, tekst ustalił oraz wstępem poprzedził J. W. Gomulicki, Państwowy Instytut Wydawniczy, Warszawa 1974, s. 5-54.

Kaleta Roman, O twórczości satyrycznej Franciszka Zabłockiego w okresie Sejmu Czteroletniego, w: tegoż, Oświeceni i sentymentalni. Studia nad literatura i życiem w Polsce w okresie trzech rozbiorów, Zakład Narodowy im. Ossolińskich - Wydawnictwo, Wrocław 1971, s. 542-596.

Kądziela Łukasz, Sapieha Kazimierz Nestor, w: Polski słownik biograficzny, t. 35, Warszawa 1994, s. 52-67.

Kostkiewiczowa Teresa, Oda, w: Słownik literatury polskiego oświecenia, red. taż, wyd. 4, Zakład Narodowy im. Ossolińskich - Wydawnictwo, Wrocław 2006, s. 322-329.

Maksimowicz Krystyna, Poezja polityczna a Sejm Czteroletni, Wydawnictwo Uniwersytetu Gdańskiego, Gdańsk 2000.

Maksimowicz Krystyna, Portretowy soterion i jego kulisy: „Powinszowanie księżnie Elżbiecie z Branickich Sapieżyn<ie> szczęśliwego do zdrowia powrócenia”, w: Czytanie Naruszewicza, [cz.] 1, red. B. Wolska, T. Kostkiewiczowa i B. Mazurkowa, Instytut Badań Literackich PAN Wydawnictwo, Warszawa 2015, s. 283-301, Czytanie Poetów Polskiego Oświecenia, t. 3, cz. 1.

Mazurkowa Bożena, Problem i przejawy panegiryzmu w poezji okolicznościowej drugiej połowy XVIII wieku, w: Panegiryk jako element życia literackiego doby staropolskiej i oświeceniowej, red. M. Sulejewicz-Nowicka, Z. Gruszka, wstęp M. Wichowa, Wydawnictwo Uniwersytetu Łódzkiego, Łódź 2013, s. 255-274.

Michalski Jerzy, Sejmiki poselskie 1788 r. (cz. II), „Przegląd Historyczny” 1960, t. 51, z. 2, s. 331-367.

Michalski Jerzy, Sejmiki poselskie 1788 roku, „Przegląd Historyczny” 1960, t. 51, z. 1, s. 52-73.

Oświeceniowa poezja imieninowa, w: Wiersze imieninowe poetów z drugiej połowy XVIII wieku, wstęp, wybór tekstów i oprac. B. Wolska, B. Mazurkowa, T. Chachulski, Instytut Badań Literackich PAN Wydawnictwo, Warszawa 2011, s. 11-84.

Platt Julian, Panegiryk, w: Słownik literatury polskiego oświecenia, red. T. Kostkiewiczowa, wyd. 4, Zakład Narodowy im. Ossolińskich - Wydawnictwo, Wrocław 2006, s. 391-395.

Toczyńska Magdalena, Spartanka i Cyganka w teatrze Franciszka Dionizego Kniaźnina, w: Kobieta epok dawnych w literaturze, kulturze i społeczeństwie, red. I. Maciejewska, K. Stasiewicz, Wydawnictwo Littera, Olsztyn 2008, s. 130-138.

Węgrzyn Iwona, Polskie piekło. Literackie biografie zdrajców targowickich: Stanisława Szczęsnego Potockiego, Franciszka Ksawerego Branickiego i Seweryna Rzewuskiego, Universitas, Kraków 2005.

Wolska Barbara, ,,Muza Ukryta pod Znakiem Herbu Syrokomli” Kajetana Kościałkowskiego, „Prace Polonistyczne" 1989, t. 45, s. 19-38.

Wolska Barbara, Ogólne uwagi o twórczości okolicznościowej Adama Naruszewicza. Wiersze podarunkowe i bukiety, „Prace Polonistyczne” 2004, t. 59: Tobie-teraz. W kregu literackich ofiarowań, s. 123-174.

Wolska Barbara, Poezja politycza czasów pierwszego rozbioru i sejmu delegacyjnego 1772-1775, Zakład Narodowy im. Ossolińskich - Wydawnictwo, Wrocław 1982, Studia z Okresu Oświecenia, t. 19. 
Wolska Barbara, Reminescencje antyczne w poezji Kajetana Kościatkowskiego na łamach „Muzy Ukrytej pod Znakiem Herbu Syrokomli”, „Prace Polonistyczne” 1985, t. 41, s. 169-190.

Zawisza Jerzy Wojciech, Panegiryczny druk okolicznościowy doby stanisławowskiej, Zakład Narodowy im. Ossolińskich - Wydawnictwo, Wrocław 1984, Śląskie Prace Bibliograficzne i Bibliotekoznawcze, t. 18.

Szymon Piotr Dąbrowski

Laudatory Verses in honour of Elżbieta Sapieżyna (neé Branicka) and her closest relatives

(Summary)

The paper is devoted to occasional laudatory verses which were written to honour princess Elżbieta Sapieżyna (née Branicka) and the members of her closest family - son Kazimierz Nestor Sapieha, General of the Lithuanian Artillery and brother Franciszek Ksawery Branicki, Great Crown Hetman. The begining of the article reminds of already known literary works containing complimentary images of the female aristocrat. The main object of author's interest are pieces that have not been noticed by scholars of the eighteenth-century political writings. These are: anonymous ode written in 1784 in connection with arrival of Sapieżyna to Prienai (pol. Preny) in Lithuania and collection of four verses created by Wojciech Zacharkiewicz, who thereby added splendour to the Franciszek Ksawery Branicki's coming to Warsaw for parliamentary sitting of the Great Sejm and to election of Kazimierz Nestor Sapieha for the Marshal of lithuanian confederation. The author discussed circumstances of the creation, main motifs of content and artistic composition of laudatory images of addressees. Furthermore he determined connections of these verses with then popular genres of occasional poetry and put Sapieżyna's complimentary portraits in context of manners of creation women's images in literary works of that time.

Keywords: occasional and political poetry; laudatory verses of the second half of the eighteenth century; panegyric; Elżbieta Sapieżyna (neé Branicka); Kazimierz Nestor Sapieha; Franciszek Ksawery Branicki

Słowa kluczowe: okolicznościowa poezja polityczna; wiersze pochwalne drugiej połowy XVIII wieku; panegiryk; Elżbieta z Branickich Sapieżyna; Kazimierz Nestor Sapieha; Franciszek Ksawery Branicki 